\title{
米国医学校における人類遺伝学の教育
}

\author{
B. Childs, C.A. Huether, and E.A. Murphy
}

Am. J. Hum. Genet. 33: 1-10, 1981

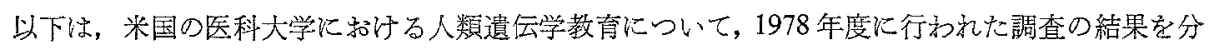
析したるのでする。これをほ济同年度に当る1979年度の日本の状況（医学課程における人類遺伝

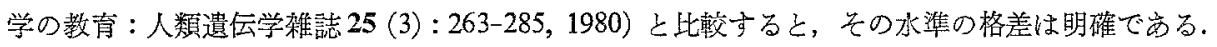
例兊ば米国では，独立の必修課程として遺云学の講義が行われている学校は, 資料の得られた大学 松の 73\% (106 校中 77 校) に達しているが，日本ではわずが $31 \%$ (55 校中 17 校)にすぎな い. 加觉て, この報告でほ，この上うな水準に達している米国の医科大学でさ觉，人類遺伀学の教 育はい亲だ質的・量的に不十分で, 改善の余地が大きいことが強調されて扣り，放置すれば彼找の 教育水準の格差，ひいては医療水準の格差は桩大する一方であることは明白で㔛る。本稿肪日本の 現状の客钼的な評価と革滞のない改善のたるの資料として利用されることる切望する.
\end{abstract}

(井上英二)

\section{抄 訳}

人類遗伝学の知見は実地医家には当惑を覚えさせるほどの速度で進展している.1975 年に全米各 地の 1,092 名の医師について行った調查は，最近 10 年間の卒業生でさえ遗伀学の知識が著しく不

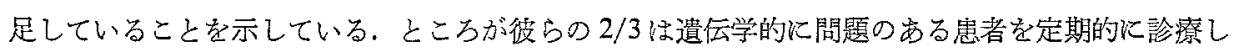

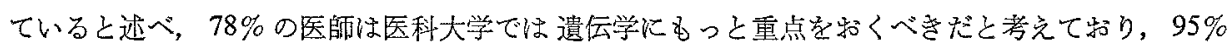
のものは卒後教育コースの中に遺伝学を含める意義を認めていた，驚くべきこと火，彼らのうちの 斈後 6 年以内の医師の半数近くは, 大学在学中に遺伝学コースを受满していなかった。

医学教育課程の中で遺伝学のため時間をさくょうになったのは最近のことで, 誰が，いっ，ど のように教觉るべきが関しては諭文が殆でない，亲た遺伝学教育の重要性についての遺伀医学者 の意見い一致していても，いかに対処してゆくがついては意見がまちまちである。

本諭文は 1978 年の米国医科大学のカシキニラムの中での遗伝学の位置づけについての報告であ る.

調査方法としては，4年制医科大学 107 校の学部長にアンケートを送付した。その内容は，1）何 学年の学生に，ぞの上うな体制で，何時問，誰がどんな講義を行っているか，2）必修科目の場合 の講義内容，3）関係する教室，4）遺伝学が予防医学の中にコースとしてあるか，5）遗伀学が卒 後教育計画の中に含まれているか否か，牤よび，6) 遺云学が総合保健科学部 (schools of allied health sciences) のカリキュラムの中化するか，であった，

また遗伝学が正規のカリキニラムに採用されている場合といない場合に，どの上うな影響がある かをみる手段として, National Board of Medical Examiners (NBME) に，アンタートに回答を 
上せた学校の学生の国家試験問題中，遺伝学に関連するものの解答結果を提供してくれるよう求め た. 遺伝学に関連する問題かどらかの決定は，3,637題の問題につきるれわれが行い，「人類遣伝 学」と「遺层生化学就よび微生物遗伝学」に分類した. NBME から占機密保持の制約がつけられ たため，学校名が判断できるような资料社得られなかった，乙たがって調查結果とすぐ比較できる ような“生”の採点資料は入手できなかった。しかし，個々の学校について遺伝学の問題の成䋶を 非遺伝学の問題の成綘で補正した形の資料の提供が得られた。

結果について述ベると，アンケートの回収率は 103/107（96.3\%）で，別炕学校案内から若干資 料のと机たるの 3 校があり，したがって 107 校中 1 校を除いて，古る程度の資料は得られたことに なる。

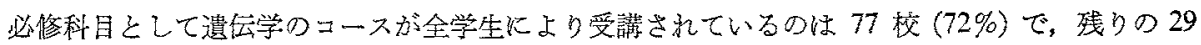
校中 8 校では遗伝学がある程度，基碟医学科目に含まれていた。遺层学のコース第 1 学年で行う のは全体の $57 \%$ ，第 2 学年以上が $34 \% ， 10 \%$ では 1 年以上にわたって実施されている. 時間数

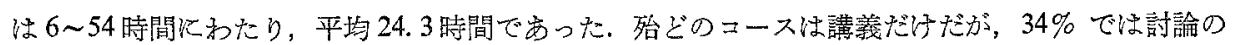
時間を含み，22\%では1〜5時間程度の実習時間証設けていた。

44 校からはコースの概略が示された（表 1). 摽準偏差が大きいことは内容の差異を反映してい る. 击る学校では第1学年で教えているのに殆ど臨床的観点で行って特り，一方，2,3校では㱠ぞ 疾患関して蛙言及していないようであった，第2学年のコースとなっている場合には，ある程度 医学との関連づけがなされているようであった．表中「臨床」とは，例えば筋ジストロフィー定， 染色体異常, 遗公相談, 出生前診断のように明らか儿医学的な項目である.

コースの責任者に学生の反応につきたずねたところ,77名中 69 名が意見を迹べた. $68 \%$ 好好評，

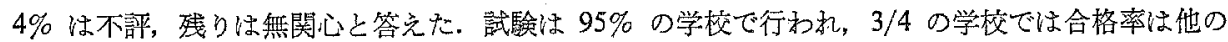
教科と同様との回答で岕った.

学校气れぞれの特質とコース之の関你については，公立・私立の別，学生数，所在地，NIH 研

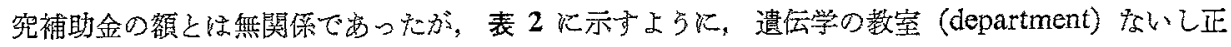
規の部門 (formal division) の有無とは強い関連怔る。小見科が部門ない乙不正規 (informal) の unit 昰もっていて授業を担当しているところが多いことも，この表からわかる。

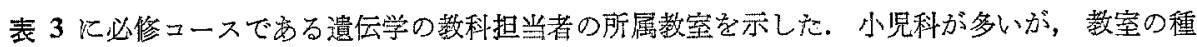

表 144 の医学校汇存在する遺伝学コースの時間㥢分

\begin{tabular}{|c|c|c|c|c|c|c|c|c|}
\hline \multirow{2}{*}{ トピック } & \multicolumn{2}{|c|}{$\begin{array}{c}\text { 第 } 1 \text { 学年 } \\
(24 \text { 校) }\end{array}$} & \multicolumn{2}{|c|}{$\begin{array}{c}\text { 筍 } 2 \text { 学年 } \\
(17 \text { 校) }\end{array}$} & \multicolumn{2}{|c|}{$\begin{array}{c}\text { 葴 年 } \\
\text { (3 校) }\end{array}$} & \multicolumn{2}{|c|}{ 総 計 } \\
\hline & 平均 & $\mathrm{SD}$ & 平均 & SD & 平均 & $\mathrm{SD}$ & 平均 & $\mathrm{SD}$ \\
\hline 臨床 & 31.2 & 13.4 & 37.7 & 13.5 & 25.0 & 6.0 & 33.4 & 13.5 \\
\hline メンデルの法則 & 28.4 & 12.7 & 20.6 & 12.8 & 31.8 & 10.2 & 25.4 & 13.0 \\
\hline 細胞遗伀学 & 17.2 & 7.4 & 17.3 & 8.2 & 15.9 & 4.1 & 17.2 & 7.4 \\
\hline 多因子形質 & 11.0 & 7.7 & 14.1 & 9.1 & 15.2 & 10.3 & 12.6 & 8.4 \\
\hline 集団遺伝学 & 10.3 & 8.7 & 9.6 & 7.0 & 12.1 & 6.2 & 10.1 & 7.8 \\
\hline 倫理 & 1.4 & 2.9 & 1.4 & 3.1 & & & 1.3 & 2.9 \\
\hline
\end{tabular}

Jpn. J. Human Genet. 
表 2 医科大学での必修人類遺伝学コースの運営単位の形隹

\begin{tabular}{|c|c|c|}
\hline 遭営単㕸 & 学校数 $(\%)$ & 必須科目 $(\%)$ \\
\hline 遗伝学教室* & $16(15.1)$ & $12(75)$ \\
\hline 内科之小巟科にと机ぞれ正規の division 市り & $10(9.4)$ & $9 \quad(90)$ \\
\hline 小罗科飞正規の division 㐫り & $39 \quad(36.8)$ & $31 \quad(79.5)$ \\
\hline 内科に正規の division 吅り & $5(4.7)$ & $2(40.0)$ \\
\hline 他教室に正規の division 五り & $12(11.3)$ & $10 \quad(83.3)$ \\
\hline 小兒科に不正規の unit 㐫り & $10(9.4)$ & $9(90.0)$ \\
\hline 他教室に不正規の unit 离り & $5(4.7)$ & $2(40.0)$ \\
\hline な炕なし & $9(8.5)$ & $2(22.2)$ \\
\hline 焧 & 106 & $77(72.6)$ \\
\hline
\end{tabular}

*2つの教室にまたがる divisionの岁る場合を含㟔。

表 3 必修科目の運営関与する教官の所属教室

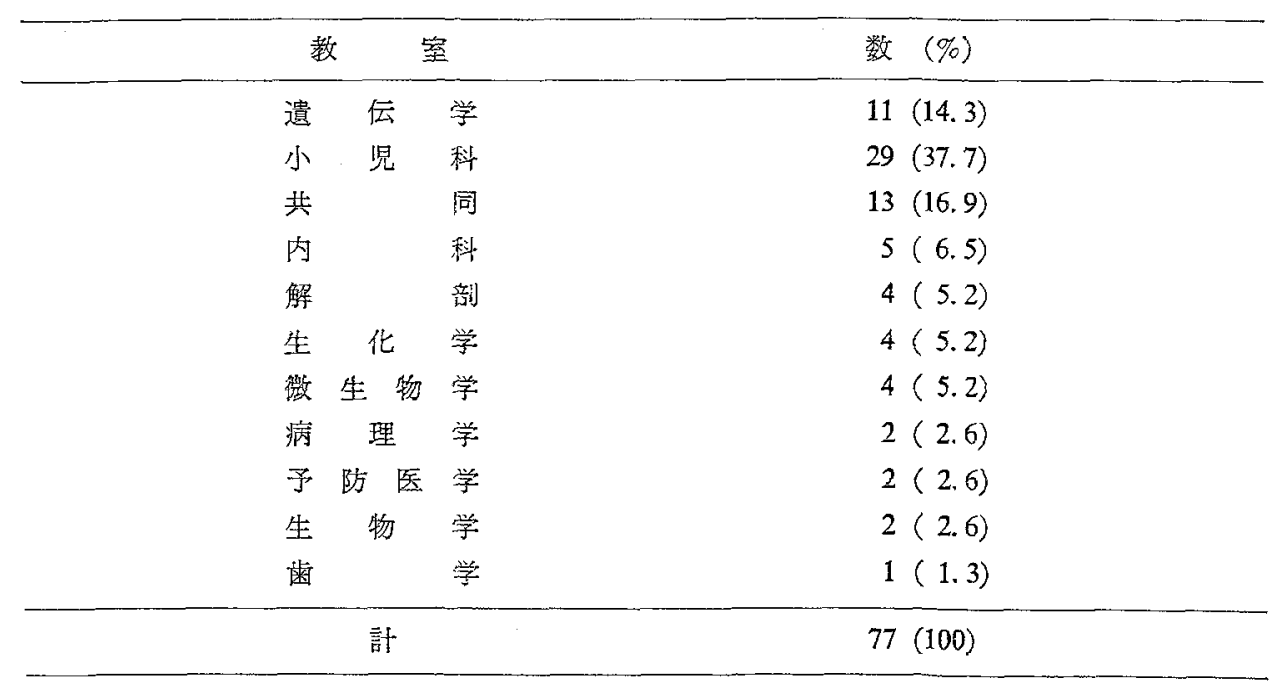

類が多いことが注目され、この表に記載したもの以外に産婦人科, 精神科, 薬理学, 放射線科, 生物

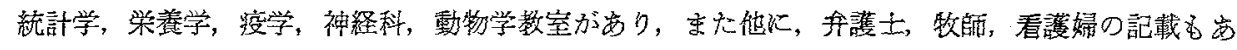
った. 13 の大学 (17\%) ではュースが共同で運営され，小览科と内科，ないし小児科と産婦人科比 よるものが多いが，2，3 の大学では基礎と臨床の教室の混合運営体制であった。

表 4 Kコースを実施する教室と実施学年との関係を示した．解剖学，遗伝学ないし生化学教室が 担当する場合には第 1 学年, 臨床部閏が担当する場合には第 2 学年で行われるとが多い.しかし 臨床と基碟の共同担当で第 1 学年か第 2 学年に講義がなされているところが数として多い，一方， 第1学年の授業の約 $1 / 4$ は臨床医の欢により行われていることもかかる.

選抧科目としての遺伝学コースについての情報は105校から得られたが,34 校では行われて括ら

Vol. 27, No. 1, 1982 
表 4 必修遗伝学コースの教育㳊関与する教官の所属教室々実施学年

\begin{tabular}{|c|c|c|c|c|}
\hline 教 官 & $\begin{array}{l}\text { 第 } 1 \text { 学年 } \\
\text { 数 }(\%)\end{array}$ & $\begin{array}{c}\text { 第 2学年 } \\
\text { 数 }(\%)\end{array}$ & $\begin{array}{c}1 \text { 年間以上 } \\
\text { 数 }(\%)\end{array}$ & 総計 \\
\hline 基砹教室の及 & $8(88.9)$ & $1(11.1)$ & - & 9 \\
\hline 遺伝学教室 & $8(80.0)$ & $2(20.0)$ & - & 10 \\
\hline 基礎（遺伝学教室学含古）々臨床 & $17(56.7)$ & $10(33.3)$ & $3(10.0)$ & 30 \\
\hline 蹊休教室のみ & $11(39.3)$ & $12(42.9)$ & $5(17.9)$ & 28 \\
\hline 計 & $44(57.2)$ & $25(32.4)$ & $8(10.4)$ & 77 \\
\hline
\end{tabular}

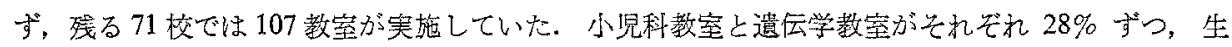

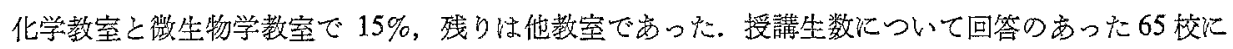
ついてみると，34校 (52\%) では定員を下回っていた。

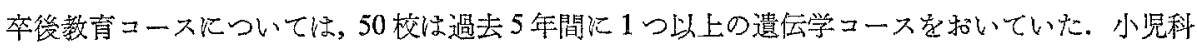

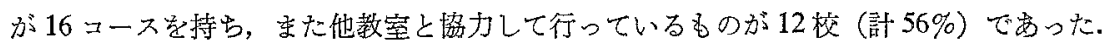

遺伝学々予防医学の関連について子ると, 97 校は予防医学に関連の深い教室 (予防医学, 地域医

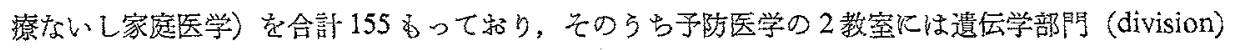

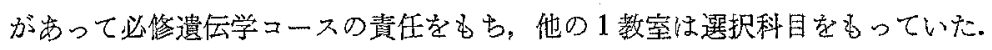

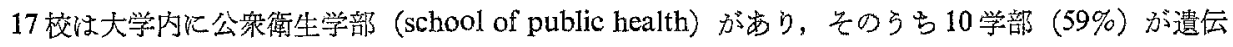
学コースを行っていた．67校では総合保健科学部をるら, そのうち8 学部 (13\%)で遺伝学コース が行われていた。

国家試験と遗伝学コース実施との関連については, 医科大学への NIH 研究補助金, ヌースを行 ろ学年, 選択科目の場合の出席率， コースの運営形態，必修科目の場合の時間数について解析し た、有意であったのほ必修科目の場合の時間数に対する国家試臨の成續 (1977 年人類遺伝学関連問 題の成績)で, 他の項目では関薑性㹥認められなかった。

\section{考察}

殆どの医科大学で情遗学を必修科目として物り，必修教科としても選択教科としても実施して

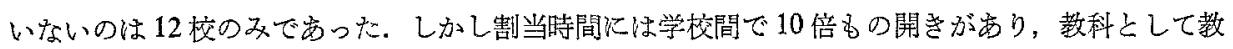
える必要があることについての認識といら点では一致しているが，どれだけの時間教えるべきかに

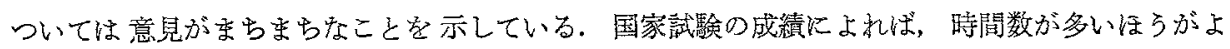
い.教科の内容について蛙基碟的な原理と臨床面の两者を含めるべきであることについては意見が 一致しているが，合の配分に大きな差暴が安る.この差異の一部はニースを受ける学年, 担当教官 の專阿関倸している.

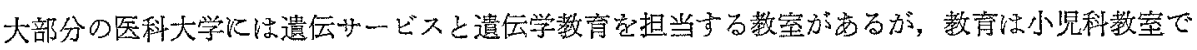
もっとも多く担当して括り，2つ以上の教室が関与する場合にす小見科医が運営責任者になってい ることが多い。これとは対照的炕内科性担当教室としても責任者としても開与することが少ない， 第 1 学年で害施する場合，ときとして遺伝学などの基礎教室が地当して基礎科学として教兄られ， 第 2 学年で勧施する場合には医学への㐫用面が强調される㣀向にある。学校によっては第 1 学年で 臨床医のみにより，臨床的観点の講義が行われているところが每るが，これは第 1 学年の学生には 
理解し難いと思われる.

選択科目の担当は小坚科教室と遗伝学教室が主であった。しかし半数以上は学生が定員に達して いない，遗伝医学の中でもっとも著しい発展をとげているのはスクリーニング款よび出生前診断を 含さ予防医学の面である. しかし, 公采蒤生学部 (school of public health) の3/5 は遗伝学コー ス設りているが，予防医学，地域医療蛙よび家庭医学の各教室では殆ど設けていない，総合保健 科学部では，これより方ずかに良い程度にず゙ない。

以上の成績から，どんな結論を引き出すことができるだらうか？授業時間数，教科の内容和よ

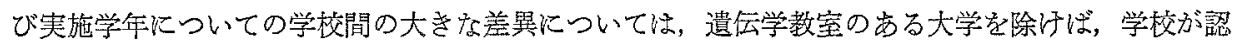

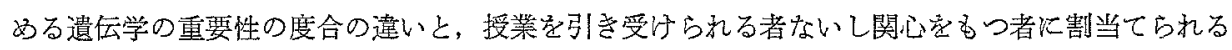

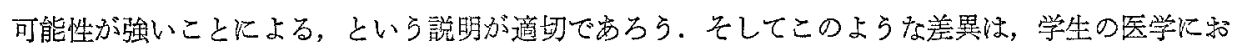
ける遗伝学の価値住する認識, 彼らの遺伝学の知識, そしてその後, 医師として急速に発展して ゆくこの分野炕㜊れずについていこうとする能力に，大きな差異を生じさせることになると考光ら れる.

遺伝学コース担当教官として小婜科医と内科医の間になぜ大きな差が生じているのだるらか？ これは怙そらく大学病院で必要とされる診断内容の反映であるう。遺伝外来汇紹介される患者の大 半注異形症候群 (dysmorphic syndrome), 先天代謝異常症, むるい他の発育異常などであり, またスクリーニングと出生前診断は，主として小見科と産科の領域である。これは医科大学の遣伝 医学者が小罗科医によってょり多くを占められる結果になり，そのことが票た，学生や教授たちに

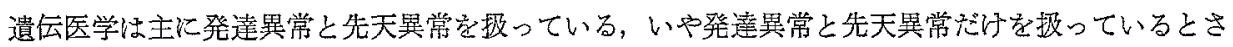

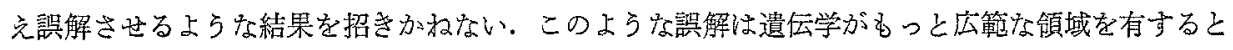
いう事実から目を奪ってしまう。

Garrod に上り初めて予知された先天買常からわれわ和が学えだのは，明白な疾病のみならず，

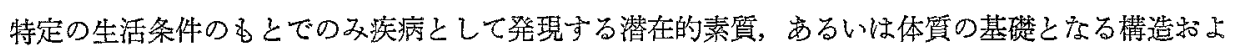

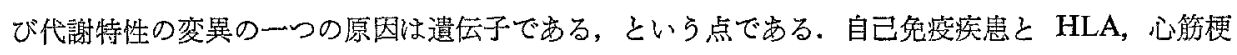
塞と低此重りポ蛋白受容体の変異, 消化性䟺瘍と血中ペプシノーゲンI 濃度などの関連性が観察さ れているが，これら遗层的成人病の“危険因子”が発見される序曲にすぎないということは䞄ど

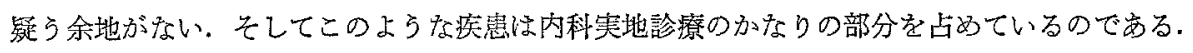

予防医学関係の教室の教官はなぜ遗伝学への関心がそしいのだろらか？一つには，遺伝医学者

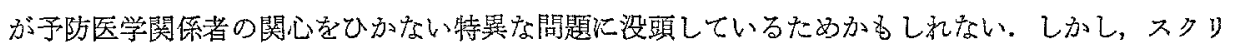
一ニングや出生前診断は既に定着して和り，“遺伝的危険因子”についても同椂でるる.集団遺伝 学とよばれる遗伝子の分布に関与る研究る，これらの医学的問題に直接関倸している。したがっ て，遺伝学の予想能力は間もなく予防医学の重要な見地となるであるう.

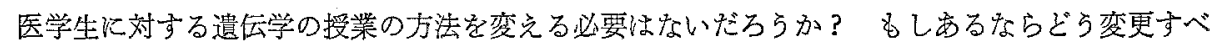

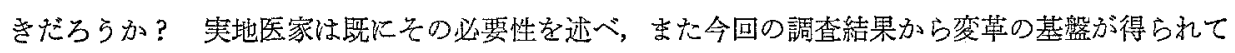
いる，選択科目で興味を示さなかった学生でさえ，必修科目にすることには熱心であった．国家試

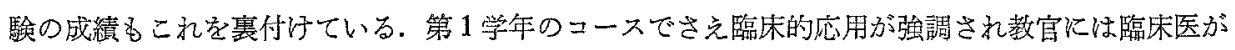

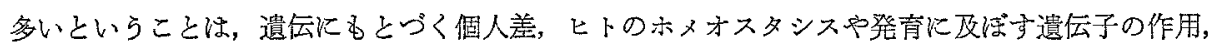
家蔟や集団の遗伝的搆成，進化の面からみた疾患といった基礎的な問題が和万そがされる恐れが あることを示唆している. 改善策として, “人類遺伝学” のコ一スを第 1 学年に, “遺伝医学”のコ 一スを第 2 小い第 3 学年にもつことがよい天゙るう。このよう柰時間配分をすれば，生化学方疾患

Vol. 27, No. 1, 1982 
の代謝面の研究にとって基礎の立場にあるの之同様に，人類遗伝学が遺伝医学汇対応する基礎であ ることを学生に理解させることができるだろら。㫗らろん他にも各大学の特質によって異なる改善 策があるに違いない。

本諭文がかかる变革をもたらすための傠議や行動を刺激し，医学思想呿よび実地診療面で遺伝学 がより広簛に受け入れられるきっかけとなれば㐋いである。 (三輪史朗，影岡武士 抄訳）

謝辞：この抄訳におたっては著者 Childs 博士括よび出版社 The University of Chicago Press の許可を得たので,ここに感謝する。

This is a summarized translation of the article entitled "Human genetics teaching in U.S. medical schools" by Barton Childs, Carl A. Huether and Edmond A. Murphy, which appeared in Am. J. Hum. Genet. 33: 1-10, 1981, by permission of The University of Chicago Press. 